\title{
Preservation of sugarcane silage with urea and calcium oxide: performance and metabolic efficiency of dairy cows
}

\author{
Conservación del ensilaje de caña de azúcar con urea y óxido de calcio: rendimiento y eficiencia \\ metabólica en vacas lecheras \\ Preservação da silagem de cana-de-açúcar com ureia e óxido de cálcio: desempenho e eficiência \\ metabólica de vacas leiteiras
}

\author{
Susi C S G Martins ${ }^{l}$ (D); Gleidson G P Carvalho²*(D); Aureliano J V Pires ${ }^{3}$ (D); Laudí C Leite ${ }^{4}$ (D); Daiane Lago-Novais² (iD);

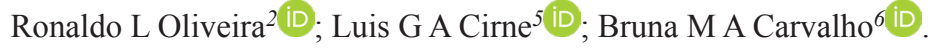

\begin{abstract}
${ }^{1}$ Instituto Federal de Educação, Ciência e Tecnologia do Norte de Minas Gerais, 39560-000, Salinas, Minas Gerais, Brasil.
${ }^{2}$ Departamento de Zootecnia, Universidade Federal da Bahia, 40170-110, Salvador, Bahia, Brasil.

${ }^{3}$ Departamento de Zootecnia, Universidade Estadual do Sudoeste da Bahia, 45700-000, Itapetinga, Bahia, Brasil.

${ }^{4}$ Departamento de Zootecnia, Universidade Federal do Recôncavo da Bahia, 44380-000, Cruz das Almas, Bahia, Brasil.

${ }^{5}$ Departamento de Zootecnia, Universidade Federal do Oeste do Pará, 68035-110, Santarém, Pará, Brasil.

${ }^{6}$ Instituto de Ciências Agrárias, Universidade Federal de Minas Gerais, 39404-547, Montes Claros, Minas Gerais, Brasil.
\end{abstract}

\section{To cite this article:}

Martins SCDSG, Carvalho GGP, Pires AJV, Leite LC, Lago-Novais D, Oliveira RL, Cirne LGA, Carvalho BMA. Preservation of sugarcane silage with urea and calcium oxide: Performance and metabolic efficiency of dairy cows. Rev Colomb Cienc Pecu 2021; 34(4): 305-315. DOI: https://doi.org/10.17533/udea.rccp.v34n4a07

\begin{abstract}
Background: Inclusion of urea and calcium oxide $(\mathrm{CaO})$ during sugarcane ensilage has been hypothesized to improve dairy cow performance. Objective: To evaluate the use of urea and calcium oxide as additives to preserve sugarcane silage quality and determine whether they improve dairy cow performance and metabolic efficiency. Methods: Four diets were used: sugarcane silage without additive (SS), sugarcane silage with $10 \mathrm{~g} / \mathrm{kg}$ urea (SU), sugarcane silage with $5 \mathrm{~g} / \mathrm{kg}$ urea $+5 \mathrm{~g} / \mathrm{kg}$ $\mathrm{CaO}$ (SUC), and sugarcane silage with $10 \mathrm{~g} / \mathrm{kg} \mathrm{CaO}$ (SC). Eight crossbred cows at approximately 100 days of lactation were distributed in two 4x4 Latin squares, and their diets were formulated to reach an average milk production of $15 \mathrm{~kg} / \mathrm{day}$. Results: Dry matter, non-fibrous carbohydrates, organic matter, total carbohydrates, and total digestible nutrient intake were the highest $(p<0.05)$ for the cows fed SC. Urinary excretion of nitrogen was higher $(p<0.05)$ for cows fed diets based on SUC than those fed diets with SC. Milk urea nitrogen content was the highest $(p<0.05)$ in animals fed SU diets. Nitrogen balance was positive in all treatments; however, the microbial protein synthesis was low for all diets. Conclusions: The diet with SU showed the highest nitrogen loss through the milk. Among the evaluated silages, those with SC and SUC are recommended to promote a high intake of nutritional components.
\end{abstract}

Received: August 2, 2019; accepted: November 3, 2020

*Corresponding author. Av. Ademar de Barros, 500, Ondina, Salvador, Bahia, Brasil. E-mail: gleidsongiordano@yahoo.com.br 
Keywords: dairy cows; digestibility; ensiling; ensilage; feed additives; intake; metabolic efficiency; microbial purines; milk urea nitrogen; nitrogen balance; performance; silage; urea.

\section{Resumen}

Antecedentes: La hipótesis fue que una dieta con combinación de urea y óxido de calcio $(\mathrm{CaO})$ para el ensilaje de caña de azúcar, puede mejorar la producción de vacas lecheras cruzadas. Objetivo: Evaluar la urea y el óxido de calcio como aditivos para preservar la calidad del ensilaje de caña de azúcar y determinar si mejoran el rendimento y la eficiencia metabólica de vacas lecheras. Métodos: Cuatro dietas fueron utilizadas: ensilaje de caña de azúcar sin aditivo (SS), ensilaje de caña de azúcar con $10 \mathrm{~g} / \mathrm{kg}$ de urea (SU), ensilaje de caña de azúcar con $5 \mathrm{~g} / \mathrm{kg}$ de urea $+5 \mathrm{~g} / \mathrm{kg} \mathrm{de} \mathrm{CaO} \mathrm{(SUC)} \mathrm{y} \mathrm{ensilaje} \mathrm{de} \mathrm{caña} \mathrm{de}$ azúcar con $10 \mathrm{~g} / \mathrm{kg}$ de $\mathrm{CaO}(\mathrm{SC})$. Ocho vacas cruzadas fueron evaluadas con una producción media de leche de $15 \mathrm{~kg} / \mathrm{día}$ y aproximadamente 100 días de lactación, distribuidas en dos cuadrados latinos 4x4. Resultados: El consumo de materia seca, carbohidratos no fibrosos, materia orgánica, carbohidratos totales y nutrientes digestibles totales fue mayor ( $\mathrm{p}<0,05$ ) cuando las vacas fueron alimentadas con dietas conteniendo SC. La excreción de nitrógeno en la orina fue mayor ( $\mathrm{p}<0,05)$ cuando las vacas fueron alimentadas con dietas basadas en SUC que las alimentadas con dietas SC. El nitrógeno ureico de la leche fue mayor $(\mathrm{p}<0,05)$ en animales alimentados con dietas con SU. El balance de nitrógeno fue positivo en todos los tratamientos, sin embargo, la síntesis de proteína microbiana fue baja para todas las dietas. Conclusión: La dieta con SU presentó la mayor pérdida de nitrógeno por medio de la leche. Entre los ensilajes evaluados, aquellos con SC y SUC son recomendados por promover un mayor consumo de componentes nutricionales.

Palabras clave: aditivos alimentarios; balance de nitrógeno; desempeño; digestibilidad; eficiencia metabólica; ensilaje; ensilado; ingestión; nitrógeno ureico en la leche; purinas microbianas; urea; vacas lecheras.

\section{Resumo}

Antecedentes: A hipótese foi que uma dieta com a mistura de ureia e óxido de cálcio $(\mathrm{CaO})$ para a ensilagem de cana de açúcar, poderia melhorar a produção de vacas leiteiras mestiças. Objetivo: Avaliar ureia e óxido de cálcio como aditivos para preservar a qualidade da silagem de cana de açúcar: melhoria da produção e eficiência metabólica de vacas leiteiras. Métodos: Quatro dietas foram utilizadas: silagem de cana de açúcar sem aditivo (SS), silagem de cana de açúcar com $10 \mathrm{~g} / \mathrm{kg}$ de ureia (SU), silagem de cana de açúcar com $5 \mathrm{~g} / \mathrm{kg}$ de ureia $+5 \mathrm{~g} / \mathrm{kg}$ de $\mathrm{CaO}$ (SUC) e silagem de cana de açúcar com $10 \mathrm{~g} / \mathrm{kg}$ de CaO (SC). Oito vacas mestiças foram avaliadas com uma produção media de $15 \mathrm{~kg} /$ dia e aproximadamente 100 dias de lactação, distribuídas em dois quadrados latinos $4 \times 4$. Resultados: O consumo de matéria seca, carboidratos não fibrosos, matéria orgânica, carboidratos totais e nutrientes digestíveis totais foi maior $(\mathrm{p}<0,05)$ quando as vacas foram alimentadas com dietas contendo $\mathrm{SC}$. A excreção de nitrogênio na urina foi maior $(\mathrm{p}<0,05)$ quando as vacas foram alimentadas com dietas baseadas em SUC do que aqueles animais alimentados com dietas SC. O nitrogênio ureico do leite foi maior $(\mathrm{p}<0,05)$ em animais alimentados com dietas com SU. O balanço de nitrogênio foi positivo em todos os tratamentos, no entanto, a síntese de proteína microbiana foi baixa para todas as dietas. Conclusão: A dieta com SU apresentou maior perda de nitrogênio por meio do leite. Entre as silagens avaliadas, aquelas com SC e SUC são recomendadas por promover maior consumo de componentes nutricionais.

Palavras-chave: aditivos alimentares; balanço de nitrogênio; desempenho; digestibilidade; eficiência metabólica; ensilagem; ingestão; nitrogênio ureico no leite; purinas microbianas; silagem; ureia; vacas leiteiras. 


\section{Introduction}

In most tropical countries, fresh sugarcane is an alternative forage used in dairy farms during the dry season. An advantage of using this crop is the agronomic yield of sugarcane, which can reach 50 tons/ha/year for one cut, which accounts for more than $620 \mathrm{~g} / \mathrm{kg}$ of total digestible nutrients (Valadares Filho et al., 2006). Additionally, the peak nutritive value of sugarcane in terms of sucrose accumulation occurs simultaneously as the senescence period of tropical pastures. However, the use of sugarcane in its fresh form requires daily cutting, which could cause differences in daily composition over the season and lead to regrowth differences throughout the field, thereby reducing crop life. Furthermore, daily cutting could increase milk production costs.

Sugarcane ensilage is an alternative for improving the logistics of forage supply, reducing operating costs, and increasing the time that sugarcane fields can be used. Nevertheless, the high content of soluble carbohydrates and yeast in the plant could lead to alcoholic fermentation during ensilage, which may cause excessive dry matter losses (Carvalho et al., 2015). The addition of chemical additives during sugarcane ensiling could improve the fermentation process and dry matter preservation (Andrade et al., 2016). Additionally, these additives could favor beneficial microorganisms, such as lactic acid bacteria, or inhibit undesirable microorganisms, such as yeasts and clostridia (Chizzotti et al., 2015). Ensilage also helps to reduce indigestible fiber content. Sugarcane has high indigestible neutral detergent fiber (iNDF) concentrations (approximately $30 \mathrm{~g} / \mathrm{kg}$ dry matter; Daniel et al. 2013). Thus, using chemical additives during ensiling could improve dry matter (DM) and iNDF digestibility by cell wall hydrolysis (Chizzotti et al. 2015; Andrade et al. 2016). Improved digestibility is another benefit of using chemical additives in silages. We hypothesized that a combination of urea and calcium oxide during sugarcane ensiling could improve intake, digestibility, nitrogen balance, and ruminal microbial synthesis in crossbred dairy cows.
Thus, an experiment was conducted to test this hypothesis.

In this context, the objective of this study was to evaluate sugarcane silage preservation with urea and calcium oxide on dairy cow performance and metabolic efficiency.

\section{Materials and methods}

\section{Ethical considerations}

All animal procedures were performed following protocols authorized by the Ethics Committee of Southwest Bahia State University, Brazil (Permit Number: 033/2010).

\section{Location}

The experiment was conducted at the Instituto Federal de Educação, Ciência e Tecnologia do Norte de Minas Gerais, Salinas, BA, Brazil (16 $10^{\circ} 13^{\prime \prime} \mathrm{S}$ and $\left.42^{\circ} 17^{\prime} 25^{\prime \prime} \mathrm{W}\right)$, and the chemical composition was determined at the Laboratory of Analysis and Animal Nutrition of Universidade Estadual do Sudoeste da Bahia, Brazil.

\section{Animals, experimental design, and diets}

Eight crossbred cows averaging 100 days of lactation were distributed in two $4 \times 4$ Latin squares consisting of four cows, four treatments (diets), and four experimental periods, with each period lasting 15 days. The first 12 days of each experimental period were used for adaptation to the diet, and the 13th to 15th days were used for data collection. Four experimental diets (Table 1) were evaluated: sugarcane silage without additive (SS or Control), sugarcane silage with $10 \mathrm{~g} / \mathrm{kg}$ urea in the fresh forage (SU), sugarcane silage with $5 \mathrm{~g} / \mathrm{kg}$ urea $+5 \mathrm{~g} / \mathrm{kg} \mathrm{CaO}$ (calcium oxide) (SUC), and sugarcane silage with $10 \mathrm{~g} / \mathrm{kg} \mathrm{CaO}$ (SC). Diets were formulated to be isonitrogenous and reach an average production of $15 \mathrm{~kg}$ milk/ day, according to the NRC (2001). 
Table 1. Proportion of ingredients and chemical composition of the experimental diets.

\begin{tabular}{|c|c|c|c|c|}
\hline \multirow{2}{*}{ Item } & \multicolumn{4}{|c|}{ Experimental diets } \\
\hline & SS & SU & SUC & SC \\
\hline \multicolumn{5}{|l|}{ Proportion of ingredients $(\mathrm{g} / \mathrm{kg} D M)^{1}$} \\
\hline Sugar cane silage & 54.2 & 55.2 & 54.7 & 54.2 \\
\hline Ground corn grain & 35.7 & 34.5 & 35,1 & 35.7 \\
\hline Soybean meal & 6.3 & 8.3 & 7.33 & 6.3 \\
\hline Mineral mix & 1.1 & 1.1 & 1.1 & 1.1 \\
\hline Dicalcium phosphate & 0.5 & 0.5 & 0.5 & 0.5 \\
\hline Limestone & 0.4 & 0.4 & 0.4 & 0.4 \\
\hline Urea & 1.8 & 0.00 & 0.9 & 1.8 \\
\hline \multicolumn{5}{|l|}{ Chemical composition $(\mathrm{g} / \mathrm{kg} \mathrm{DM})^{1}$} \\
\hline Dry matter ${ }^{2}$ & 52.0 & 51.4 & 52.5 & 52.5 \\
\hline Organic matter ${ }^{2}$ & 92.3 & 94.2 & 90.9 & 88.9 \\
\hline Crude protein ${ }^{2}$ & 14.1 & 14.6 & 14.2 & 13.4 \\
\hline Ether extract ${ }^{2}$ & 2.1 & 1.9 & 2.3 & 2.1 \\
\hline Neutral detergent insoluble nitrogen ${ }^{3}$ & 11.4 & 10.1 & 9.2 & 12.2 \\
\hline Acid detergent insoluble nitrogen ${ }^{4}$ & 7.1 & 6.4 & 6.2 & 7.1 \\
\hline Acid detergent fiber ${ }^{2}$ & 35.9 & 34.8 & 33.3 & 31.4 \\
\hline Neutral detergent fiber corrected for ash and protein ${ }^{2}$ & 43.1 & 40.0 & 40.1 & 37.4 \\
\hline Indigestible neutral detergent fiber & 18.5 & 16.6 & 17.2 & 18.2 \\
\hline Lignin $^{2}$ & 5.1 & 4.9 & 4.5 & 4.3 \\
\hline Non-fibrous carbohydrates corrected for ash and protein ${ }^{2}$ & 29.6 & 29.3 & 32.0 & 34.5 \\
\hline Total carbohydrates ${ }^{2}$ & 72.7 & 69.4 & 72.1 & 71.9 \\
\hline
\end{tabular}

${ }^{1} \mathrm{SS}$ : sugarcane silage without additive; SU: sugarcane silage with $10 \mathrm{~g} / \mathrm{kg}$ urea; SUC: sugarcane silage with $5 \mathrm{~g} / \mathrm{kg}$ urea $+5 \mathrm{~g} /$ $\mathrm{kg} \mathrm{CaO}$; and SC: sugarcane silage with $10 \mathrm{~g} / \mathrm{kg} \mathrm{CaO} .{ }^{2}$ Percentage of dry matter. ${ }^{3}$ Percentage of total $\mathrm{N}$. ${ }^{4}$ Percentage of total $\mathrm{N}$.

\section{Feeding, performance, and digestibility}

Feed was provided twice daily at 08.00 and $16.00 \mathrm{~h}$, and it was adjusted, so there was no more than $100 \mathrm{~g} / \mathrm{kg}$ leftover. Cows were machinemilked twice daily at 07.30 and $15.30 \mathrm{~h}$ from the 13th to 15 th day of each experimental period, and the individual milk production was recorded. The $4 \%$ fat-corrected milk (FCM) was calculated according to Sklan et al. (1992).

Feces were collected directly from the rectum twice daily at 08.00 and $16.00 \mathrm{~h}$ from the 13th to 15th day of each experimental period. The estimated production of fecal dry matter (DM) was determined using indigestible neutral detergent fiber (iNDF) as an internal marker (Detmann et al., 2007). The iNDF was used as an internal marker to estimate the apparent digestibility coefficients and was obtained after $240 \mathrm{~h}$ of ruminal incubation time.

\section{Chemical and biological analyses}

Dry matter $(\mathrm{DM})$, organic matter $(\mathrm{OM})$, and crude protein (CP) analyses were performed according to the AOAC (2000) methods number 934.01 for DM, 930.05 for OM, and 981.10 for $\mathrm{CP}$. Ether extract (EE) was analyzed according to the AOAC (2000), method number 920.39. Neutral detergent fiber (NDF) contents corrected for ash and protein (NDFap) were estimated following Mertens (2002) procedure, with corrections performed as recommended by Mertens (2002) and Licitra et al. (1996), respectively. Lignin was determined according to the AOAC (2002) 
by solubilization of cellulose with $72 \%(\mathrm{w} / \mathrm{v})$ sulfuric acid. Nonfibrous carbohydrates corrected for ash and protein (NFCap) were calculated as proposed by Hall (2003).

Non-fibrous carbohydrates corrected for diet ash and protein (NFCap) were estimated according to Hall (2000), in which NFCap (\%) = $100-[\%$ CPdiet $-\%$ CPurea $+\%$ Ureadiet $)+\%$ EE + NDFap + \%MM)], while total carbohydrates (TC) were estimated as proposed by Sniffen et al. (1992), as follows: $\mathrm{TC}=100-(\% \mathrm{CP}+\% \mathrm{EE}$ $+\% \mathrm{MM})$.

Urine collection was performed as a spot sampling after spontaneous urination approximately $4 \mathrm{~h}$ after supplying the morning feed. The samples were filtered with cheesecloth, and a $10-\mathrm{ml}$ aliquot was separated and diluted with $40 \mathrm{ml}$ sulfuric acid $(0.036 \mathrm{~N})$ to quantify urinary concentrations of urea, creatinine, uric acid, and allantoin (Valadares et al., 1999).

Urinary concentrations of creatinine, uric acid, allantoin and urea nitrogen (UUN), and milk urea nitrogen (MUN) were determined by enzymatic-colorimetric assays using commercial kits (Bioclin, Belo Horizonte, Brazil). Urinary allantoin content was estimated by a colorimetric method as specified by Chen and Gomes (1992). Daily creatinine excretion was used to estimate total urine volume by spot sampling, and it was $24.05 \mathrm{mg} / \mathrm{kg}$ body weight (BW) (Chizzotti et al., 2006).

Urine volume was estimated from the relationship between total creatinine excretion $(\mathrm{mg} / \mathrm{kg} \mathrm{BW})$ and the average concentration of creatinine $(\mathrm{mg} / \mathrm{L})$ in each spot sample. The result was multiplied by the body weight of the respective animal.

Excretion of total purine derivatives (TP) was estimated by adding the amount of allantoin and uric acid excreted in urine and milk allantoin. Absorbed microbial purine (mmol/day) was estimated from total purine excretion (mmol/day) using the equation proposed by Verbic et al. (1990).
Ruminal microbial nitrogen (g MN/day) was estimated from the amount of absorbed purines (mmol/day) according to the equation by Chen and Gomes (1992). In the present study, values of 70 for $\mathrm{N}$ content in purines $(\mathrm{mg} / \mathrm{mmol}), 0.83$ for intestinal digestibility of microbial purine and 0.116 for the ratio of purine $\mathrm{N}$ :total $\mathrm{N}$ were used. Efficiency of microbial protein synthesis was determined by dividing microbial protein synthesis ( $\mathrm{g} /$ day) by total digestible nutrient intake ( $\mathrm{kg} /$ day).

Nitrogen balance (NB) was calculated as the difference between total nitrogen intake (total $\mathrm{N}$ ) and total nitrogen excreted in feces (feces $\mathrm{N}$ ), and urine (urine $\mathrm{N}$ ) and secreted in milk (milk N). Total nitrogen in feces and urine was determined according to the methodology described by AOAC (2000), and milk nitrogen was analyzed by enzymatic and spectrophotometric analyses (Chemspec 150 Analyzer, Piracicaba, Brazil).

\section{Statistical analysis}

All results were subjected to analysis of variance using the SAEG statistical program. Tukey's test was performed to compare the means with a $5 \%$ probability of type-I error.

\section{Results}

The DMI (expressed in $\mathrm{kg} /$ day and as $\mathrm{g} / \mathrm{kg}$ BW) was higher $(p<0.05)$ in cows fed the SC or SUC diets; however, it was lower in cows fed the SU diet (Table 2). The CP intake did not differ among diets $(\mathrm{p}>0.05)$. The NFCap intake differed $(\mathrm{p}<0.05)$ among diets and was lower in cows fed the SU diet compared to animals fed the SUC, and SC diets. Besides, the $\mathrm{CaO}$ content in the diets contributed to improved nutritive value of silages by reducing the NDFap content (Table 1) and increasing the NFCap intake.

Higher OM intake $(\mathrm{p}<0.05)$ was observed in cows fed the SC and SUC diets compared to animals fed the SU diet. However, it did not differ ( $p>0.05$ ) among animals fed these diets, and cows fed the SS diet. The SU diet promoted 
a lower intake of OM and NFCap. This result demonstrates the positive effect of $\mathrm{CaO}$ for inhibiting the loss of nutrients in the silage. The TDN intake was higher $(\mathrm{p}<0.05)$ in cows fed SC and SUC than in animals fed the SU diet.

Thus, diets containing sugarcane silage with $\mathrm{CaO}$ resulted in higher intake of DM and most nutrients. In contrast, cows fed the SU diet had the lowest intake of DM and nutrients.

Apparent digestibility of DM, NDFap, MO, and TDN did not differ ( $p>0.05)$ among diets (Table 3). The highest apparent digestibility of CP $(p<0.05)$ was observed when cows were fed the SU diet, and the lowest in animals fed the SC diet. This result is probably due to the higher percentage of soluble nitrogen in the SU diet, which negatively affected intake. The highest apparent digestibility of EE $(p<0.05)$ was observed in cows fed the SS or SUC diets, and the lowest digestibility was observed in animals fed the SC diet. This result agrees with the intake of $\mathrm{EE}$, which was higher for these same diets. The highest apparent digestibility of NFCap $(p<0.05)$ was observed in cows fed the SC diet, and the lowest digestibility in animals fed the SU diet. Similar apparent digestibility of TC was observed among the SS, SUC, and SC diets $(p>0.05)$. Besides, the lowest apparent digestibility of TC was observed in cows fed the SU diet.

Nitrogen balance was positive in all tested diets; i.e., the amount of nitrogen consumed by the animals was higher than that excreted (in feces and urine) and secreted in the milk. This result confirms that crude protein was not lacking in the diets. However, whether this protein is completely metabolizable remains unclear. The $\mathrm{N}$ intake $(\mathrm{g} /$ day $)$ was lower $(\mathrm{p}<0.05)$ in cows fed $\mathrm{SS}$, and SC diets compared to animals fed the SUC diet (Table 4). Although SS or SC provided higher DMI, the amount of $\mathrm{N}$ intake was lower. This result probably reflects the fact that diets formulated with urea ( 5 and $10 \mathrm{~g} / \mathrm{kg}$ ) had higher $\mathrm{N}$ concentrations.

Cows fed the SUC diet had higher urinary excretion of nitrogen $(p<0.05)$ than animals fed the SC diet (Table 4). However, there was no difference in urinary excretion of nitrogen among cows fed SS, SU, and SUC diets.

Table 2. Daily intake of nutrients in crossbred cows fed diets containing sugarcane silage treated with urea and calcium oxide.

\begin{tabular}{|c|c|c|c|c|c|c|}
\hline \multirow{2}{*}{ Item } & \multicolumn{4}{|c|}{ Silage $^{1}$} & \multirow{2}{*}{ SEM } & \multirow{2}{*}{ P-value } \\
\hline & SS & SU & SUC & SC & & \\
\hline $\mathrm{DM}(\mathrm{kg} / \text { day })^{2}$ & $11.9 \mathrm{ab}$ & $9.7 \mathrm{~b}$ & $13.3 \mathrm{a}$ & $13.2 \mathrm{a}$ & 0.389 & 0.013 \\
\hline DM (g/kg BW) & $21.4 \mathrm{ab}$ & $17.8 \mathrm{~b}$ & $23.5 \mathrm{a}$ & $23.6 \mathrm{a}$ & 0.622 & 0.010 \\
\hline NDFap $(\mathrm{kg} / \text { day })^{3}$ & 5.7 & 5.1 & 6.0 & 5.6 & 0.145 & 0.197 \\
\hline NDFap (g/kg BW) & 10.2 & 9.2 & 10.6 & 9.9 & 0.249 & 0.196 \\
\hline NFCap (kg/day) ${ }^{4}$ & $3.7 \mathrm{bc}$ & $3.1 \mathrm{c}$ & $4.4 \mathrm{ab}$ & $4.7 \mathrm{a}$ & 0.129 & 0.001 \\
\hline $\mathrm{OM}(\mathrm{kg} / \text { day })^{5}$ & $11.1 \mathrm{ab}$ & $9.2 \mathrm{~b}$ & $12.4 \mathrm{a}$ & $12.1 \mathrm{a}$ & 0.363 & 0.021 \\
\hline CP $(\mathrm{kg} / \text { day })^{6}$ & 1.9 & 2.3 & 2.3 & 1.9 & 0.085 & 0.137 \\
\hline $\mathrm{EE}(\mathrm{kg} / \text { day })^{7}$ & $0.29 \mathrm{a}$ & $0.22 \mathrm{~b}$ & $0.34 \mathrm{a}$ & $0.23 \mathrm{~b}$ & 0.008 & 0.000 \\
\hline iNDF $(\mathrm{kg} / \text { day })^{8}$ & 2.5 & 2.2 & 2.5 & 2.4 & 0.089 & 0.521 \\
\hline TDN $(\mathrm{kg} / \text { day })^{9,} 10$ & $7.8 \mathrm{ab}$ & $6.5 \mathrm{~b}$ & $8.6 \mathrm{a}$ & $8.9 \mathrm{a}$ & 0.255 & 0.015 \\
\hline
\end{tabular}

Means with the same letter within the same row do not differ based on Tukey's test at $5 \%$ significance. ${ }^{1} \mathrm{SS}$ : sugarcane silage without additives; SU: sugarcane silage with $10 \mathrm{~g} / \mathrm{kg}$ urea; SUC: sugarcane silage with $5 \mathrm{~g} / \mathrm{kg}$ urea $+5 \mathrm{~g} / \mathrm{kg} \mathrm{CaO}$; and SC: sugarcane silage with $10 \mathrm{~g} / \mathrm{kg} \mathrm{CaO}$. SEM: standard error of the mean. ${ }^{2} \mathrm{DM}$ : dry matter. ${ }^{3} \mathrm{NDF} a p$ : neutral detergent fiber corrected for ash and protein. ${ }^{4} \mathrm{NFCap}$ : non-fibrous carbohydrates corrected for ash and proteins. ${ }^{5} \mathrm{OM}$ : organic matter. ${ }^{6} \mathrm{CP}$ : crude protein. ${ }^{7} \mathrm{EE}$ : ether extract. ${ }^{8} \mathrm{iNDF}$ : indigestible neutral detergent fiber. ${ }^{9} \mathrm{TDN}$ : total digestible nutrients. ${ }^{10}$ Estimate via equations from the NRC (2001). 
Table 3. Nutrient digestibility and milk production in crossbred cows fed diets containing sugarcane silage treated with urea and calcium oxide.

\begin{tabular}{|c|c|c|c|c|c|c|}
\hline \multirow{2}{*}{ Item } & \multicolumn{4}{|c|}{ Silage $^{1}$} & \multirow{2}{*}{ SEM } & \multirow{2}{*}{ P-value } \\
\hline & SS & SU & SUC & $\mathrm{SC}$ & & \\
\hline \multicolumn{7}{|c|}{ Nutrient digestibility $(\mathrm{g} / \mathrm{kg})$} \\
\hline $\mathrm{DM}^{2}$ & 644.5 & 604.3 & 639.1 & 637.9 & 6.28 & 0.128 \\
\hline $\mathrm{CP}^{3}$ & $678.5 \mathrm{ab}$ & $746.2 \mathrm{a}$ & $675.6 \mathrm{ab}$ & $639.0 \mathrm{~b}$ & 10.75 & 0.016 \\
\hline $\mathrm{EE}^{4}$ & $714.7 \mathrm{a}$ & $672.7 \mathrm{ab}$ & $701.0 \mathrm{a}$ & $554.6 \mathrm{~b}$ & 18.17 & 0.020 \\
\hline NDFap ${ }^{5}$ & 519.8 & 543.6 & 511.9 & 487.0 & 11.52 & 0.402 \\
\hline $\mathrm{NFCap}^{6}$ & $813.2 \mathrm{ab}$ & $744.5 \mathrm{~b}$ & $789.6 \mathrm{ab}$ & 834.6 a & 10.39 & 0.034 \\
\hline $\mathrm{TC}^{7}$ & $660.4 \mathrm{a}$ & $597.3 \mathrm{~b}$ & $658.4 \mathrm{a}$ & $661.3 \mathrm{a}$ & 6.67 & 0.005 \\
\hline $\mathrm{OM}^{8}$ & 677.6 & 631.7 & 666.8 & 671.9 & 6.06 & 0.058 \\
\hline $\mathrm{TDN}^{9}$ & 614.0 & 577.9 & 594.3 & 592.4 & 6.24 & 0.138 \\
\hline \multicolumn{7}{|c|}{ Milk production ( $\mathrm{kg} /$ day) } \\
\hline Milk production & 13.6 & 13.2 & 14.9 & 14.9 & 0.25 & 0.050 \\
\hline
\end{tabular}

Means with the same letter within the same row do not differ based on Tukey's test at 5\% significance. ${ }^{1} \mathrm{SS}$ : sugarcane silage without additive; SU: sugarcane silage with $10 \mathrm{~g} / \mathrm{kg}$ urea; SUC: sugarcane silage with $5 \mathrm{~g} / \mathrm{kg}$ urea $+5 \mathrm{~g} / \mathrm{kg} \mathrm{CaO}$; and SC: sugarcane silage with $10 \mathrm{~g} / \mathrm{kg} \mathrm{CaO}$. SEM: standard error of the mean. ${ }^{2} \mathrm{DM}$ : dry matter. ${ }^{3} \mathrm{CP}$ : crude protein. ${ }^{4} \mathrm{EE}$ : ether extract. ${ }^{5} \mathrm{NDFap}$ : neutral detergent fiber corrected for ash and protein. ${ }^{6} \mathrm{NFCap}$ : non-fibrous carbohydrates corrected for ash and proteins.

${ }^{7} \mathrm{TC}$ : Total carbohydrates. ${ }^{8} \mathrm{OM}$ : organic matter. ${ }^{9} \mathrm{TDN}$ : total digestible nutrients.

Table 4. Nitrogen balance, efficiency of nitrogen utilization, concentrations and excretion of nitrogen in milk and urine, synthesis of microbial N, microbial efficiency, and feed efficiency in lactating crossbred cows fed diets containing sugarcane silage with urea and calcium oxide.

\begin{tabular}{|c|c|c|c|c|c|c|}
\hline \multirow{2}{*}{ Item } & \multicolumn{4}{|c|}{ Silage $^{1}$} & \multirow{2}{*}{ SEM } & \multirow{2}{*}{ P-value } \\
\hline & SS & SU & SUC & SC & & \\
\hline Intake N (g/day) & $348.3 \mathrm{~b}$ & $381.6 \mathrm{ab}$ & $398.7 \mathrm{a}$ & $352.3 \mathrm{~b}$ & 5.01 & 0.004 \\
\hline \multicolumn{7}{|c|}{ Total $N$ excretion (g/day) } \\
\hline Milk & 74.2 & 71.2 & 79.2 & 75.8 & 1.90 & 0.407 \\
\hline Urine & $140.4 \mathrm{ab}$ & $162.8 \mathrm{ab}$ & $168.2 \mathrm{a}$ & $133.9 \mathrm{~b}$ & 4.32 & 0.026 \\
\hline Feces & 98.1 & 94.4 & 119.1 & 104.8 & 4.02 & 0.174 \\
\hline Nitrogen balance & 35.7 & 53.2 & 32.3 & 37.8 & 4.38 & 0.364 \\
\hline \multicolumn{7}{|c|}{ Efficiency of Nitrogen utilization } \\
\hline $\mathrm{MUN}^{2}$ & $1.2 \mathrm{~b}$ & $2.2 \mathrm{a}$ & $1.5 \mathrm{ab}$ & $1.1 \mathrm{~b}$ & 0.04 & 0.000 \\
\hline $\mathrm{UUN}^{3}$ & 229.2 & 237.7 & 223.1 & 212.8 & 8.77 & 0.786 \\
\hline \multicolumn{7}{|c|}{ Milk production (kg/day) } \\
\hline Microbial efficiency ${ }^{4}$ & 108.1 & 105.5 & 94.8 & 105.1 & 6,36 & 0.885 \\
\hline Feed efficiency ${ }^{5}$ & $1.3 \mathrm{ab}$ & $1.6 \mathrm{a}$ & $1.2 \mathrm{~b}$ & $1.2 \mathrm{~b}$ & 0.04 & 0.007 \\
\hline
\end{tabular}

Means with the same letter within the same row do not differ based on Tukey's test at $5 \%$ significance. ${ }^{1} \mathrm{SS}$ : sugarcane silage without additive; SU: sugarcane silage with $10 \mathrm{~g} / \mathrm{kg}$ urea; SUC: sugarcane silage with $5 \mathrm{~g} / \mathrm{kg}$ urea $+5 \mathrm{~g} / \mathrm{kg} \mathrm{CaO}$; and SC: sugarcane silage with $10 \mathrm{~g} / \mathrm{kg} \mathrm{CaO}$. SEM standard error of the mean. ${ }^{2}$ milk urea nitrogen. ${ }^{3}$ allantoin and urea nitrogen. ${ }^{4} \mathrm{~g} \mathrm{CP} /$ $\mathrm{kg}$ TDN. ${ }^{5} \mathrm{~kg}$ milk/kg DM. 
Higher MUN excretion $(p<0.05)$ was observed in cows fed the SU diet than animals fed SC and SS diets (Table 4). There was no effect $(\mathrm{p}>0.05)$ of diet on fecal excretion of nitrogen, nitrogen balance, UUN, and microbial efficiency ( $\mathrm{g} \mathrm{CP} / \mathrm{kg}$ TDN) (Table 4).

The highest feed efficiency $(p<0.05)$ was observed in cows fed the SU diet, whereas the lowest averages were observed in animals fed SUC, and SC diets.

\section{Discussion}

The SU differed from the other diets, and it decreased DMI by approximately $26.0 \%$ compared to the other silages with $\mathrm{CaO}$, which was related to high ammonia concentration in the silage. High ammonia concentration was also observed by Martins et al. (2015) when they studied qualitative parameters of sugarcane silages treated with urea and calcium oxide. Ammonia gives off a very strong smell, reducing food palatability and DMI. Ingestion was expected to be lower for cows fed diets containing SS mainly due to the loss of nutrients and soluble carbohydrates caused by alcoholic fermentation and high fiber content, which could limit intake due to rumen fill. However, DMI for the control diet was $18.2 \%$ higher than that obtained with the SU diet. This lower intake of the SU diet was possibly due to its lower palatability and TDN:CP ratio (4.1 SS vs. 2.8 SU), which may have compromised the efficiency of microbial protein synthesis and, consequently, DMI (Medeiros and Marino, 2015).

Although NDFap content decreased with the inclusion of additives (urea and calcium oxide), their digestibility did not improve (Table 3). Higher digestibility values for fibrous components in the diets added with $\mathrm{CaO}$ were expected compared with sugarcane silages without additives. Similar result was reported by Jacovaci et al. (2017) who assessed the nutritive value of sugarcane silage treated with calcium oxide, and by Roth et al. (2018), who evaluated the effect of calcium oxide on the nutritional characteristics of sugarcane silage. However, NDFap intake was low (Table 2), confirming that intake was not limited by rumen fill. Thus, the $\mathrm{CaO}$ in sugarcane silage acted on fiber solubilization and improved the nutritional quality of silage.

The $\mathrm{N}$ intake results were consistent with values reported by Carvalho et al. (2011), who evaluated sugarcane treated with calcium oxide in diets of dairy heifers and observed a reduction in $\mathrm{N}$ intake (g/day) related to modification of fermentation patterns caused by $\mathrm{CaO}$ usage. The average $\mathrm{N}$ balance found in our study was $39.72 \mathrm{~g} /$ day and did not differ among diets. These results are consistent with those reported by Carvalho et al. (2011), who evaluated four $\mathrm{CaO}$ doses $(0,0.75,1.5$, and $2.25)$ in diets containing sugarcane for dairy heifers and found a $\mathrm{N}$ balance of $61.20,45.40$, 21.20 , and $16.10 \mathrm{~g} /$ day, respectively. In the present study, total $\mathrm{N}$ excretion in urine was higher for the diet with SUC and lower for the diet with SC.

Although this diet did not promote a higher intake of nitrogen, a lack of synchronization was observed between the use of dietary protein and energy, which may have caused significant MUN excretion. The UUN excretion did not differ among diets. According to Van Soest (1994), increases in nitrogen intake are associated with high urea production in the liver and high urea excretion in urine. Average microbial nitrogen was $125.67 \mathrm{~g} /$ day, which was lower than that reported by Mendonça et al. (2004) at $193 \mathrm{~g}$ /day for cows consuming diets based on sugarcane or corn silage. This result was also lower than the 278 to $419 \mathrm{~g} /$ day range observed by Valadares et al. (1999) in high-producing cows. Sousa et al. (2009) found a mean value of $198.87 \mathrm{~g}$ /day of microbial $\mathrm{N}$, which was similar to that obtained by Mendonça et al. (2004). In this study, the average microbial efficiency value was 103.37 g CP mic/kg TDN, which was lower than the NRC (2001) level of $130 \mathrm{~g} \mathrm{CP} \mathrm{mic/kg} \mathrm{TDN.}$ 
Among the evaluated diets, those with sugarcane silage treated with $\mathrm{CaO}$ at a concentration of $10 \mathrm{~g} / \mathrm{kg} \mathrm{CaO}$ or with a combination of $5 \mathrm{~g} / \mathrm{kg}$ urea $+5 \mathrm{~g} / \mathrm{kg} \mathrm{CaO}$ based on fresh material are recommended. Diets containing sugarcane silage with $10 \mathrm{~g} / \mathrm{kg}$ urea represent less efficient nitrogen metabolism due to high excretion of UUN and MUN, and reduced DMI.

\section{Declarations}

\section{Funding}

The authors thank FAPESB (Fundação de Amparo à Pesquisa do Estado da Bahia) for financial support.

\section{Conflicts of interest}

The authors declare they have no conflicts of interest with regard to the work presented in this report.

\section{Author contributions}

Susi CSG Martins designed the study, collected and analyzed the data, drafted and revised the manuscript. Gleidson GP Carvalho designed the study, analyzed the data, drafted and revised the manuscript. Aureliano $\mathrm{J} \mathrm{V}$ Pires, Laudí C Leite, Daiane Novais-Eiras, Ronaldo L Oliveira, Luis G A Cirne, and Bruna M A Carvalho collected and analyzed the data, and revised the manuscript.

\section{References}

Andrade FL, Rodrigues JPP, Detmann E, Valadares Filho SC, Castro MMD, Trece AS, Silva TE, Fischer V, Weiss K, Marcondes MI. Nutritional and productive performance of dairy cows fed corn silage or sugarcane silage with or without additives. Trop Anim Health Prod 2016; 48(4): 747-753. DOI: https://doi.org/10.1007/s11250-016-1020-y

AOAC. Official Methods of Analysis. Association of Official Analytical Chemists. $17^{\text {th }}$ ed. Washington (DC): USA; 2000.
AOAC. Official Methods of Analysis. Association of Official Analytical Chemists. $16^{\text {th }}$ ed. Arlington (VA): USA; 2002.

Carvalho GGP, Garcia R, Pires AJV, Detmann E, Silva RR, Pereira MLA, Santos AB, Pereira TCJ. Nitrogen metabolism in heifers fed with diets containing sugar cane treated with calcium oxide. Braz J Anim Sci 2011; 40(3): 622-629. DOI: https://doi.org/10.1590/S1516-35982011000300022

Carvalho BF, Ávila CLS, Miguel MGCP, Pinto JC, Santos MC, Schwan RF. Aerobic stability of sugar-cane silage inoculated with tropical strains of lactic acid bacteria. Grass Forage Sci 2015; 70(2): 308-323. DOI: https://doi.org/10.1111/gfs.12117

Chen XB, Gomes MJ, editors. Estimation of microbial protein supply to sheep and cattle based on urinary excretion of purine derivatives - an overview of technical details. Bucksburnd: Rowett Research Institute/International Feed Research Unit 21 (Occasional publication); 1992.

Chizzotti ML, Valadares Filho SC, Valadares RFD, Chizzotti FHM, Campos JMS, Marcondes MI, Fonseca MA. Intake, digestibility and urinary excretion of urea and purine derivatives in heifers with different body weights. Braz J Anim Sci 2006; 35(4): 1813-1821. DOI: https://doi.org/10.1590/S1516-35982006000600032

Chizzotti FHM, Pereira OG, Valadares Filho SC, Chizzotti ML, Rodrigues RTS, Tedeschi LO, Silva TC. Does sugar cane ensiled with calcium oxide affect intake, digestibility, performance, and microbial efficiency in beef cattle. Anim Feed Sci Technol 2015; 203: 23-32. DOI: https://doi.org/10.1016/j.anifeedsci.2014.12.014

Daniel JLP, Santos MC, Zopollatto M, Huhtanen P, Nussio LG. A data-analysis of lime addition on the nutritive value of sugarcane. Anim Feed Sci Technol 2013; 184(1-4): 17-23. DOI: https://doi.org/10.1016/j.anifeedsci.2013.05.009 
Detmann E, Souza AL, Garcia R, Valadares Filho SC, Cabral LS, Zervoudakis JT. Evaluation of internal markers long term bias in a digestion assay with ruminants. Braz $\mathrm{J}$ Vet Anim Sci 2007; 59(1): 182-188. DOI: https://doi.org/10.1590/S0102-09352007000100030

Hall MB. Neutral detergent-soluble carbohydrates: nutritional relevance and analysis. Gainesville (FL): University of Florida; 2000.

Hall MB. Challenges with non-fiber carbohydrate methods. J Anim Sci 2003; 81(12): 3226-3232. DOI: https://doi.org/10.2527/2003.81123226x

Jacovaci FA, Jobim CC, Schmidt P, Nussio LG, Daniel JLP. A data-analysis on the conservation and nutritive value of sugarcane silage treated with calcium oxide. Anim Feed Sci Technol 2017; 225: 1-7. DOI: https://doi.org/10.1016/j.anifeedsci.2017.01.005

Licitra G, Hernandez TM, Van Soest PJ. Standardization of procedures for nitrogen fractionation of ruminant feeds. Anim Feed Sci Technol 1996; 57(4): 347-358. DOI: https://doi.org/10.1016/0377-8401(95)00837-3

Martins SCSG, Carvalho GGP, Pires AJV, Silva RR, Leite LC, Pereira FM, Mota ADS, Nicory IMC, Cruz CH. Qualitative parameters of sugarcane silages treated with urea and calcium oxide. Semina: Ciênt. Agrár. 2015; 36(2): 1135-1144. DOI: https://doi.org/10.5433/1679-0359.2015v36n2p1135

Medeiros SR, Marino CT. Proteínas na nutrição de bovinos de corte. In: Nicacio AC, Nunez AJC, Marino CT, Nogueira E, Feltrin GB, Oliveira LOF, Albertini TZ, Bungenstab DJ, Gomes RC, Medeiros SR, editors. Nutrição de bovinos de corte. Brasilia (DF): EMBRAPA; 2015. p.27-44.

Mendonça SS, Campos JMS, Valadares Filho SC, Valadares RFD, Soares CA, Lana RP, Queiroz AC, Assis A, Pereira MLA. Nitrogenous compounds balance, microbial protein production and plasma urea concentration in dairy cows fed sugar cane-based diets. Braz J Anim Sci 2004; 33(2): 493-503. DOI: https://doi.org/10.1590/S1516-35982004000200028
Mertens DR. Gravimetric determination of amylase-treated neutral detergent fiber in feeds withrefluxingin beakers or crucibles: collaborative study. J AOAC Int 2002; 85(6):1217-1240.

National Research Council. Nutrient requirements of dairy cattle. 7nd ed. Washington (DC): National Academy Press; 2001.

Roth APTP, Siqueira GR, Rabelo CHS, Moretti MH, Härter CJ, Resende FD, Reis RA. Effect of days postburning and calcium oxide on the fermentation, aerobic stability and nutritional characteristics of sugarcane silage for finishing Nellore steers. Grass and Forage Sci 2018; 73(3): 1-14. DOI: https://doi.org/10.1111/gfs.12377

Sklan DR, Ashkennazi R, Braun A, Devorin A, Tabori K. Fatty acids, calcium soaps of fatty acids, and cottonseeds fed to high yielding cows. J Dairy Sci 1992; 75(9): 2463-2472. DOI: https://doi.org/10.3168/jds.S0022-0302(92)78008-4

Sniffen CJ, O'connor JD, Van Soest PJ, Russel JB. A net carbohydrate and protein system for evaluating cattle diets. II. Carbohydrate and protein availability. J Anim Sci 1992; 70(11): 3562-3577. DOI: https://doi.org/10.2527/1992.70113562x

Sousa DP, Campos JMS, Valadares Filho SC, Valadares RFD, Sediyama CAZ, Cruz JCC. Fermentative parameters, microbial protein production, plasma and milk urea concentration and nitrogen balance of milking cows fed maize silage or sugarcane with whole cottonseed. Braz J Anim Sci 2009; 38(10): 2063-2071. DOI: https://doi.org/10.1590/S1516-35982009001000029

Valadares RFD, Broderick GA, Valadares Filho SC, Clayton MK. Effect of replacing alfafa silage with high moisture corn on ruminal protein synthesis estimated from excretion of total purine derivatives. J Dairy Sci 1999; 82(12): 2686-2696. DOI: https://doi.org/10.3168/jds.S0022-0302(99)75525-6

Valadares Filho SC, Magalhães KA, Rocha Júnior VR, Capelle ER. Tabelas Brasileiras de Composição de alimentos para bovinos. $2^{\text {nd }}$ ed. Viçosa (MG): UFV; 2006. 
Van Soest PJ. Nutritional ecology of the ruminant. $2^{\text {nd }}$ ed. Ithaca (NY): Cornell University Press; 1994.

Verbic J, Chen XB, Macleod NA. Excretion of purine derivatives by ruminants. Effect of microbial nucleic acid infusion. $\mathrm{J}$ Agric Sci 1990; 114(3): 243-248. DOI: https://doi.org/10.1017/S0021859600072610 